\title{
HALAL TOURISM COMMUNICATION FORMATION MODEL IN WEST JAVA, INDONESIA
}

\author{
Susie PERBAWASARI \\ University Padjadjaran, Faculty of Communication Sciences, Street of Bandung Sumedang \\ KM 21, Jatinangor, West Java, Indonesia, 45363, email: susie.perbawasari@unpad.ac.id

\section{Dian Wardiana SJUCHRO} \\ University Padjadjaran, Faculty of Communication Sciences, Street of Bandung Sumedang \\ KM 21, Jatinangor, West Java, Indonesia, 45363, email: dian.wardiana@unpad.ac.id
}

\begin{abstract}
Yanti SETIANTI
University Padjadjaran, Faculty of Communication Sciences, Street of Bandung Sumedang KM 21, Jatinangor, West Java, Indonesia, 45363, email: yanti.setianti@unpad.ac.id
\end{abstract}

\section{Aat Ruchiat NUGRAHA}

University Padjadjaran, Faculty of Communication Sciences, Street of Bandung Sumedang KM 21, Jatinangor, West Java, Indonesia, 45363, email: ruchiat@unpad.ac.id

\section{Iskandar MUDA*}

University Sumatera Utara, Faculty Economic and Business, Department of Accounting, Street Prof. TM Hanafiah 12, Padang Bulan, Medan, Indonesia, 20155, email: iskandar1@usu.ac.id

Citation: Perbawasari, S., Sjuchro, D.W., Setianti, Y., Nugrahar, A.R., \& Muda, I. (2019). HALAL TOURISM COMMUNICATION FORMATION MODEL IN WEST JAVA, INDONESIA. GeoJournal of Tourism and Geosites, 25(2), 309-320. https://doi.org/10.30892/gtg.25203-361

\begin{abstract}
This study aims to know a Halal tourism communication model. This research methods was conducted based on qualitative methods with data collection techniques through observation and Focus Group Discussions. The results in this study are Halal tourism communication models formed in West Java are still topdown (procedural top-up). The success of a tourism destination development is determined by good planning and phasing which will guide the development steps. A series of steps and activities need to be carried out in developing Halal tourism destinations. In an effort to achieve the objectives of Halal tourism activities, attention is needed from various interest groups that are cross-sectoral.
\end{abstract}

Key words: Destinations, Communication Models, Halal Tourism, Sharia Tourism Stakeholders

\footnotetext{
* Corresponding author
} 
Susie PERBAWASARI, Dian Wardiana SJUCHRO,

Yanti SETIANTI, Aat Ruchiat NUGRAHAR, Iskandar MUDA

\section{INTRODUCTION}

In 2015, foreign tourists visiting Indonesia only reached 20 percent or 2 million of the total tourist visits to Indonesia. Whereas 2016 reached 2.4 million people who visited. For the year 2018-2019, the Ministry of Tourism predicts Indonesia will be visited by around 5 million Muslim tourists. The countries of Malaysia, Turkey and the United Arab Emirates are the best Halal tourism agents in the world referring to the data from Ministry of Tourism Republic of Indonesia in 2019 that Indonesia is developing the potential of Halal tourism in 10 regions which are used as pilot projects for other areas prepared for Halal tourism destinations. And among the ten regions are West Nusa Tenggara, Aceh Special Region, and West Sumatra provinces which have received the first Halal tourism certification internationally. Halal tourism is a tourism concept that has the potential to be developed. The world Muslim population is predicted to reach $26.5 \%$ in 2030 (Babaoğlan, 2019). The expenditure of Muslim tourists is predicted to reach 200 billion dollars by 2020. At present, almost all countries in the world are beginning to attract Middle Eastern tourists, such as Malaysia, Singapore, Japan, Korea, Thailand and others. Furthermore, in 2018 the central government strives for the provinces of West Java and South Sulawesi to be certified as Halal tourism areas at the international level.

The vision of the central government, represented by the Ministry of Tourism regarding the development of Halal tourism for the West Java province, was chosen because natural resources and social resources can meet the criteria as varied and creative Halal tourist destination objects. With the ownership of natural potential and population that is quite abundant in West Java, it can be used as social capital in the development of dignified Halal tourist destination objects. Therefore, the West Java provincial government expects the support of every tourism stakeholders to be able to provide ideas, investments and other tangible forms in terms of developing creative, innovative, dignified and culturally based Halal tourist destinations. This is consistent with the results of a study conducted by Bakar (2013) which states that the development of interactive multimedia is an alternative to improve the quality of information and publications on tourism objects and creative industry products.

Halal tourism is a newly developed type of tourism based on the values of Islamic religious beliefs characterized by friendliness in services, the feasibility of religious facilities, the diversity of guaranteed Halal food, sharia lodging places, and other technical matters related to tourism (Abdullah \& Lui, 2018; Chianeh et al., 2018; Thang, 2018; Omar, 2019; Sarkar \& George, 2019). On the other hand, for West Java, the tourism object is the fourth largest contributor to the regional budget after oil and gas, coal and palm oil. Increasing regional income through tourism is supported by the role of tourists in knowing and visiting a tourist destination. Which is where tourists' knowledge of tourist destinations is supported by the role of publicity from a very good tourist destination by managers to inform about products and services offered to potential tourists so that they are interested in visiting (Nurrachmi, 2018; Sofield, 2018; Bashir et al., 2019; Han et al., 2019; Kaneko et al., 2019; Manan et al., 2019). As a province with the most population provide fresh air for the development of Halal tourism destination business which is quite significant.

Looking at the future situation and conditions for the development of Halal tourism business in Indonesia, the business opportunity to create Halal tourism in the West Java region is still wide open, especially supported by the majority of the population of West Java who is Muslim, friendly, creative and intellectual. In addition, the process of developing a Halal tourism business can be strengthened through legislation regulated as well as urgent external intervention for changes in tourism services based on religious 
concepts. The West Java Provincial Government encourages investors to invest in the tourism industry, especially for accommodation services, restaurants, especially in Regencies/cities that do not yet have international standard tourism facilities.

In order to support the development of integrated vision of Halal tourism in terms of policy, it is necessary to have a synergy between the Ministry of Tourism, Provincial Government, the community, tourism industry and universities to strengthen West Java's bargaining position as the most important tourist destination in Indonesia and Southeast Asia to able increase economic growth and people's welfare around Halal tourism. Therefore, the synergy between tourism stakeholders in West Java is needed with the government, academics, business people, the community and the mass media. Related to the development of Halal tourism, especially those that occur in regencies/cities in West Java, there are some who have started pioneering Halal tourism businesses, including Bandung, Cianjur, Sukabumi, and West Bandung (Nugraha et al., 2017). However, the existence of tourist destinations in the Regencies/cities in West Java in terms of infrastructure and superstructure is still under development. In the future, this tourism destination in West Java has great potential, but currently, there are still some problems that hinder tourism development such as inadequate facilities, access roads to tourist attractions, support from related parties or stakeholders, human resources, levies wild, and so on. Facilities are the main support for a place including tourism. If the contained in tourism facilities are inadequate, this will have an impact on the satisfaction of visitors.

Based on the phenomenon that occurs around tourist destinations in the West Bandung regency, it is true that the readiness of the tourism communication model that has not been formed due to the lack of human resources (HR) is still an obstacle to realizing Halal tourism programs (Nugraha \& Prastowo, 2017). Even though the main requirements in developing Halal tourism services in addition to the tourism objects are good, namely the carrying capacity of qualified human resources in serving tourists. In fact, the community around the tourist attraction does not really understand how to manage a creative and quality tourist spot. This is certainly one of the factors that might cause the development of Halal-based tourist destinations in existing cultural tourism places. The potential of nature combined with the concept of religion is now a potential source of inspiration in increasing the high selling power for economic growth and in the practice of communication, the development of Halal tourist destinations is still very limited. Without communication, people's perceptions will become "wild", so that the image that appears in the minds of domestic and foreign tourists becomes immeasurable and unclear. Based on evidenced, the lack of information in the mass media regarding Halal tourist destinations that have been visited by many visitors in the West Java region.

Even though the presence, growth, and dominance of the development of Halal tourist destinations programmed by the provincial government are intensively being carried out. Some of these field findings and secondary data are the basis for conducting research on the design of Halal tourism communication models in the West Java region with case studies in several Regencies/cities in West Java. In general, the purpose of research is expected to help provide solutions for the government and the community to solve problems in the field of tourism management, especially in the field of promotion tourism to the wider community. Based on the phenomena and field data above, the researcher conducted a study on how to design a Halal tourism communication model in the West Java region that could be used as a role model in other regions which are more or less developing creative Halal tourist destinations. Therefore, the problem can be formulated in this research which is to describe and explain how the process of forming a Halal tourism communication model in the West Java region? 


\section{LITERATURE REVIEW Halal Tourism}

Halal tourism is actually not much different from tourism in general. Halal tourism is a tourist concept that makes it easy for Muslim tourists to fulfill their travel needs. These needs include: the existence of Halal-certified restaurants, the availability of mosques in public places, the existence of separate swimming pool facilities of men and women, and others (Battour et al., 2018). There are six needs of Muslim tourists (Deputy for Policy Development Tourism, 2015). The Halal tourism industry must provide these six needs (1) there are Halal food and products, (2) prayer facilities; (3) toilet with washing facilities; (4) Ramadan service or fasting; (5) the management of tourist attractions and inns must guarantee the absence of immoral activities and (6) provide facilities for certain activities that are between men and women. Halal Tourism Destinations is a segment that has a large market share. The factor that drives Muslim tourists to travel Tourism is the factor of Halal food. Demographic Muslim tourists are mostly Millennials and Generation Z. Based on the opinion of Vargaz \& Perano (2018), the groups (post Millennial) are very connected to the environment around them. The internet and social environment play an important role in the journey of a Muslim who wants to ensure that the products they get are in accordance with their Islamic rules that require product attributes to be Halal, Authentic, Affordable and Accessible. This shows Halal Tourism is an important requirement and must be fulfilled.

Previously, Halal products imagined were only food products, drinks, medicines and cosmetics that do not contain alcohol or chemicals containing pig, blood and carcasses. However now there has been an evolution in the Halal industry to the product finance (such as banking, insurance, etc.) to the product lifestyle (travel, hospitality, recreation and health care). Sector Islamic economy which has experienced significant growth in lifestyle products in the tourism sector are sharia tourism. In several countries in the world, sharia travel terminology using several names that are quite diverse including Islamic Tourism, Halal Friendly Tourism Destination, Halal Travel, MuslimFriendly Travel Destinations, Halal lifestyle, and others (Wardi et al., 2018). Sharia tourism is seen as a new way to develop Indonesian tourism that upholds Islamic culture and values. So far, sharia tourism is perceived as a tour to the cemetery (pilgrimage) or to the mosque. In fact, sharia tourism is not interpreted as such, but tourism which comes from nature, culture, or artificial which is framed with Islamic values.

The development of sharia tourism is not an exclusive tour because non-Muslim tourists can also enjoy sharia-ethical services. Sharia tourism not only covers the existence of pilgrimage and religious tourist attractions, but also includes the availability of supporting facilities, such as restaurants and hotels that provide Halal food and prayer places (Kamarudin \& Ismail, 2018; Mustafa, 2019; Omar, 2019; Wannasupchue et al., 2019). Tourist products and services, as well as tourist destinations in sharia tourism are the same as general tourism as long as they do not conflict with Islamic values and ethics. Sharia tourism is an activity supported by various facilities and services provided by the community, entrepreneurs, government, and local governments that fulfill sharia provisions (Han et al., 2019). Sharia tourism is used by many people because of the characteristics of its products and services that are universal. Travel products and services, tourist objects, and tourist destinations in sharia tourism are the same as products, services, objects and tourism destinations in general as long as they do not conflict with values and sharia ethics. So sharia tourism is not limited to religious tourism.

\section{Halal Tourism Concept}

The concept of sharia which is not contrary to Islamic values and ethics related to the concept of Halal and Haram in Islam. Halal is interpreted as justified, while haram is 
interpreted as prohibited. The concept of Halal can be seen from two perspective that is religious perspective and industry perspective (Hasanah \& Harun, 2018; Oktadiana \& Pearce, 2018; Waehama et al., 2018). What is meant is with a religious perspective, that is, as a law what food is permissible consumed by Muslim consumers according to their beliefs. This brings consequence of consumer protection. Whereas from perspective industry. For food producers, this Halal concept can be interpreted as a business opportunity. For the food industry that targets its consumers most Muslims, there is a need to guarantee the Halal product increase its value in the form of intangible value.

Examples of food products whose Halal label is more attractive to Muslims consumers (Hamzah \& Yudiana, 2015). Sharia tourism is wider than religious tourism, namely tourism based on Islamic sharia values. As recommended by the World Tourism Organization (WTO), sharia travel consumers are not only Muslims but also nonMuslims who want to enjoy local wisdom. The general criteria for sharia tourism are; first, have an orientation to the common good. Second, have an orientation of enlightenment, refreshment, and calmness. Third, avoid polytheism and reconciliation. Fourth, free from immorality. Fifth, maintain security and comfort. Sixth, preserve the environment. Seventh, respecting socio-cultural values and local wisdom.

\section{Main Indicators of Sustainable Tourism}

The World Tourism Organization (UNWTO) in 2016 has published a Guidebook for Indicators of Sustainable Tourism Development in Tourism Destination Indicators of Sustainable Tourism. This handbook is designed to help identify key issues and indicators that can help managers respond effectively and maintain what makes tourist destinations feasible and attractive. In its implementation, there are 12 (twelve) stages of the procedure to define and apply these indicators. This procedure is a phased approach, which produces operational indicators in tourist destinations, ideally integrated with ongoing planning and management processes to strengthen their effectiveness. The 12 stages are (Haq \& Medhekar, 2019): A. Research and Organization; Step 1. Definition / delineation of tourist areas; Step 2. Use of participatory processes; Step 3. Identification of tourism assets and risks; Step 4. Long-term vision in tourist areas; B. Development of indicators; Step 5. Selection of priority issues; Step 6. Identify desired indicators; Step 7. Inventory of data sources; Step 8. Selection Procedure; C. Implementation; Step 9. Feasibility/implementation evaluation; Step 10. Data collection and analysis; Step 11.Accountability, communication and reporting; Step 12. Monitoring and evaluating application indicators. The issues that are the baseline issues for sustainable tourism development are (Sutono, 2019): 1. local community satisfaction with tourism activities; The basic indicators measured on this issue are: the level of satisfaction of the local community towards tourism activities. 2. Impact of tourism on local communities; The basic indicators measured on this issue are: 1) the ratio of tourist arrivals to local tourist sites; 2) the percentage who believe that tourism has helped bring new services or infrastructure and 3) the amount and capacity of social services available to the community 3. Tourist satisfaction; The basic indicators measured on this issue are 1) Level of satisfaction by visitors; 2) Perception of the value of money; and 3) Percentage of returning visitors 4. Tourist season; The basic indicators measured on this issue are 1) Tourist visits in the month or quarter; 2) Occupancy rates for licensed (official) accommodation per month (peak period relative to low season) and\% of all occupations in the peak quarter or month; 3) \% of business premises open throughout the year; and 4) The number and\% of tourism industry jobs that are permanent or full year 5 . Economic benefits of tourism; The basic indicators measured on this issue are 1) The number of local residents (and the ratio of men to women) employed in the tourism sector (also the 
ratio of tourism employment to the number of jobs); 2) Income generated by tourism as \% of the total income generated in the community. 6. The energy management; The basic indicators measured on this issue are 1) Energy consumption per capita from all sources; 2) Percentage of businesses participating in energy conservation programs or implementing energy saving policies and techniques; 3) \% of energy consumption from renewable resources (at destination, place of business) 7. Availability and utilization of water; The basic indicators measured on this issue are; 1 ) Use of water (total volume consumed and liters per tourist per day); and 2) Water savings and 8. Quality of drinking water.

\section{RESEARCH METHODS}

The method used in this study is a qualitative method. In qualitative research, according to (Kuntoro, 2009) researchers try to understand behavior and institutions by knowing well the number of people involved, values, rituals, symbols, and their beliefs. Qualitative research is essentially observing people in their environment, interacting with them, trying to understand their language and interpretations of the world around them by going down to the field and being in a place of research in a certain period of time (Nasution, 1996). The type of research design used descriptive method. According to Subana and Sudrajat (2011), descriptive research tells and interprets data relating to facts, circumstances, variables, and phenomena that occur when research takes place and presents it as is. In descriptive research, researchers did not control the situation during the study. To obtain the required data, the author carries out the steps for collecting data as follows:

1. In-depth interviews to get data in accordance with reality.

Interviews were conducted to get information about Halal tourist destinations, patterns of interaction between communities, communication systems and culture in tourism areas.

2. Systematic and participatory observation

Observations in the form of observations of Halal tourism activities, patterns of community interaction, communication and cultural in the tourism area, recorded a symptom with the help of instruments and recorded it in order to obtain the required data from the informants.

3. Literature/library study

The researcher uses various references relating to the reality under study. The required documents consist of words and images that have been recorded without the intervention of the researcher, which are available in the form of writing, notes, sound, images, and digital. The informants in this study were stakeholders involved in the development of Halal tourist areas. Determination of this resource person is done purposively and fulfills the conditions set by Taylor and Bogdan (1993), namely: 1) research subjects are willing to accept the presence of researchers; 2) capable and willing to express past and present experiences; and 3) having something interesting, for example having special experiences.

\section{RESULT AND DISCUSSION \\ Result}

\section{The Background of Halal Tourism Concept Emergence in West Java}

One that can affect macroeconomics is the political and ideological system implemented by a country or region, including the development of Islamic economics as part of the representation of the world economy influenced by sharia ideology which is the foundation of its development (Boğan \& Sarışı, 2019; Yamaguchi, 2019). This 
condition is strengthened as the results of Awalia's research (2017) which states that the government perspective Michael Foucault's social post-modern theory of discourse and power presents a power elite capable of creating a new discourse on Halal tourism to strengthen its political dominance. The focus of sharia economic development in these years can be categorized as increasing. This is evidenced by the significant increase in the Islamic economic sector including culinary, financial, insurance, clothing, cosmetics, entertainment and tourism (Suharko et al., 2018; Yousaf \& Xiucheng, 2018).

Regarding one of the sharia business developments in the tourism sector, the Indonesian government is targeted to be able to organize a model of Halal tourism area that is easily visited by foreign tourists. The definition of Halal tourism is "various kinds of tourism activities and supported by permissible facilities and services in Islam that meet the needs of Muslim tourists, provided by the local community, fellow tourists, the government, local governments, and entrepreneurs" (Ministry of Tourism, 2019). The tourism development can be relied upon in increasing local revenue (PAD) to support existing development (Olya \& Al-ansi, 2018). The emergence of the concept of sharia tourism, which is better known as Halal tourism, is a form of demand where product demands on each product must be Halal both in process and outcome. The Halal tourism there are 4 basic things needed as Muslims in carrying out tourism activities, including: the need to purify with water; the need for facilities and infrastructure for worship; the need for food that is guaranteed Halal; and the need for tourism activities that do not conflict with Islamic values such as there is no element of pornography/porno-action (immoral) and disobedience (Mariska \& Shelton, 2018).

The concept of Halal tourism continues to grow along with the development of business in Muslim-majority countries who are members of an Organization of Islamic Conference (OIC) that runs the wheel of business and commerce rapidly, the participation of multinational companies from the Arabian Peninsula, information technology that supports inter-state connectivity, and strengthening Islamic ideology after the collapse of communism in the Soviet Union. Some of these reasons make the products that will be a favorite for Muslim residents are products that are labeled Halal.

Thus, the development of the Halal tourism industry in several Muslim-populated countries began to be pioneered by professionals, especially in Indonesia. West Java as one of the regions with the most Muslim population is now developing Halal tourism areas in several Regencies/cities including Pelabuhan Ratu Beach in Sukabumi Regency, Green Canyon in Pangandaran Regency, Kawah Putih in Bandung Regency; Taman Safari Indonesia in Bogor Regency, Depok City Golden Dome Mosque, Ciater in Subang Regency; and Lembang Tourism, West Bandung Regency. The seven tourism regions have become pilot projects of the West Java provincial government to revive tourism potential, especially those based on Sharia. On the other hand, the emergence of the concept of Halal tourism is one fulfillment of the lifestyle of today's Muslims who have become new economic forces because they are involved as producers and consumers of the tourism industry who have become part of the lifestyle of most people in this millennial era (Heydari et al., 2018; Isa et al., 2018; Akhtar et al., 2019).

Basically, the development of Halal tourism is not an exclusive tour because even non-Muslim tourists can enjoy tourism services that are ethical in Sharia. The existence of the seven Halal tourism development destinations is a challenge for the people and government of West Java to be able to implement it well or vice versa. Therefore, to ensure that several Regencies/cities in West Java have been established for Halal tourism promotion events can be used as a source of information regarding the implementation of Halal tourism communication models in the West Java region, 
including Garut Regency and Pangandaran Regency. The choice of the two regions is inseparable from several well-known tourist destinations. Pangandaran is famous for marine tourism while Garut with mountainous nature tourism, culinary, and Sundanese culture. Therefore, based on the results of observations, interviews, and FGDs, it was found that Halal tourism in the Garut and Pangandaran areas was still limited to discourse at the level of government institutions and had not yet become the political will of the Regency government. This indicates that the implementation of Halal tourism in West Java is still limited to socialization that has not touched the level of legal aspects in the form of Regional Regulations and Governor Regulations.

Based on the results of the focus group discussion (FGD) in Garut Regency, it was stated that Halal tourism is a concept that is likely to be different from Sharia tourism. This is because Halal tourism focuses more on the process of serving food for Muslims when traveling somewhere". This shows that the knowledge and understanding of the community, especially among tourism activists, do not yet have the same perception regarding the concept of Halal tourism which is heralded by the central government and the provincial government. From a number of informants studied in the Pangandaran region in the Focus Group Discussion (FGD) in Garut Regency stated that here only carry out activities to provide beach tourism services plus other tours around Pangandaran such as the Grand Canyon, Batu Hiu, Citumang. However, for the concept of Halal tourism, we have only heard from the Tourism Office without any intention to find out more about the concept of Halal tourism in Pangandaran. The informants in Pangandaran Regency gave a statement that Halal tourism had indeed been delivered by the government, but until now the concept could be said to be suspended animation. This is stated because the process of developing tourism in Pangandaran Regency is still focused on the development and improvement of tourism infrastructure around Pangandaran coast which is a very promising source of local revenue.

The Process of Establishing a Halal Tourism Communication Model in West Java

The success of a tourism destination development is determined by good planning and phasing which will guide the development steps. A series of steps and activities need to be carried out in developing Halal tourism destinations. In an effort to achieve the objectives of Halal tourism activities, attention is needed from various interest groups that are cross-sectoral. This is in accordance with the results of research from Anugrah et al., (2017) which states that a region has Halal tourism potential, if it is supported in the form of regional regulations, at least contained in the Regional Tourism Development Master Plan. With the Master Plan, it can become the basis for formal policymaking related to the preparation to support Halal tourism in an area. To get effective results of communication, efforts must be made so that the parties have an awareness that the place has the potential to become Halal tourism. Furthermore, information and communication channels need to be developed both directly and through media (online and offline). The information and communication channels are built to strengthen coordination between business people, Indonesian Ulama Council/Halal Guarantee Agency and related agencies. Based on the results of a study in the field, it can be seen that the Halal tourism communication model can be explained like the chart in Figure 1.

From the Figure 1 above, it can be explained as follows: the communication model formed in Halal tourism is more linear, which means that the government as the regulator in setting a place to be developed into a tourism destination on limited communication media in the form of information, guidebooks and discussions among the public who is interested in developing Halal tourism is visiting Muslim and non- 
Muslim tourists. The media is through the process of socialization and mentoring among groups of tourism activists as well as the Department of Tourism in the area. The meetings conducted with informants who said that most of the community was half-half in accepting the concept of Halal tourism. This is because there is no guarantee that a destination conceptualized as Halal tourism will provide business benefits. In addition, the political will of the government in each region is different regarding the implementation of the concept of Halal tourism. Through the tourism communication model that has been formed, there has been interaction and influence in the social process. However, the expected level of achievement is still limited.

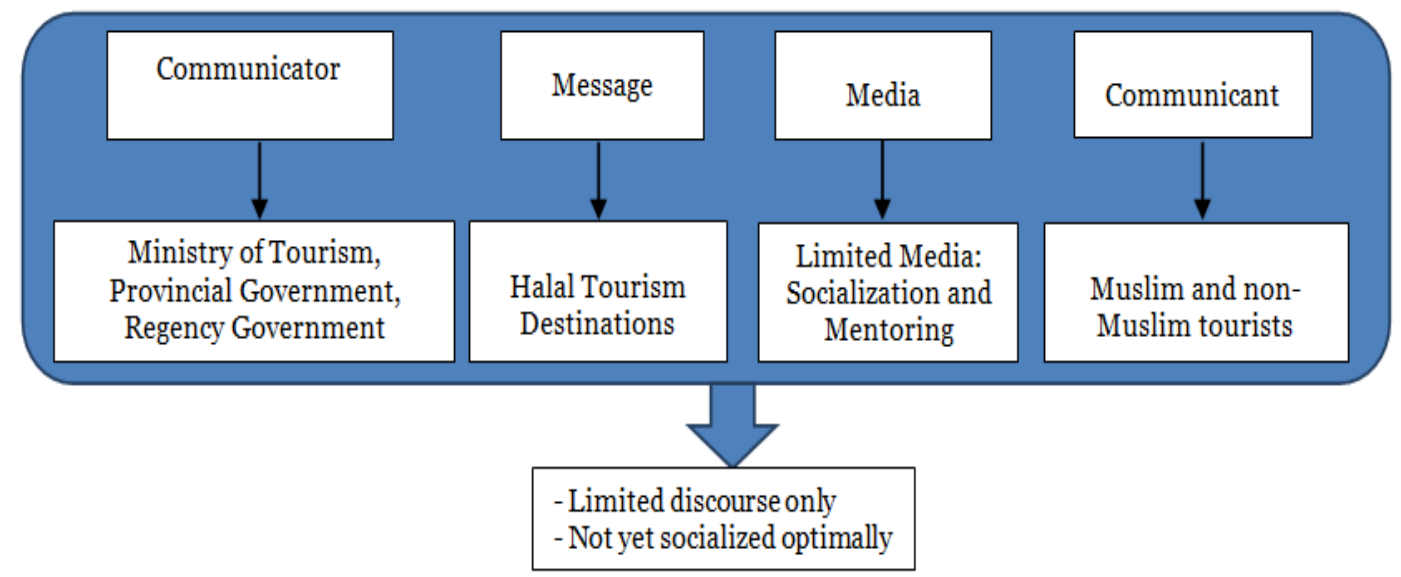

Figure 1. Communication Model for Establishing Halal Tourism

The communication model is a representation of the phenomenon of communication by highlighting the most important elements in order to understand the communication process (Vardiansyah, 2004).

The development of Halal tourism will contribute to improving the economy of the community on the condition that it is managed professionally and supported by all elements of interest groups related to tourism.

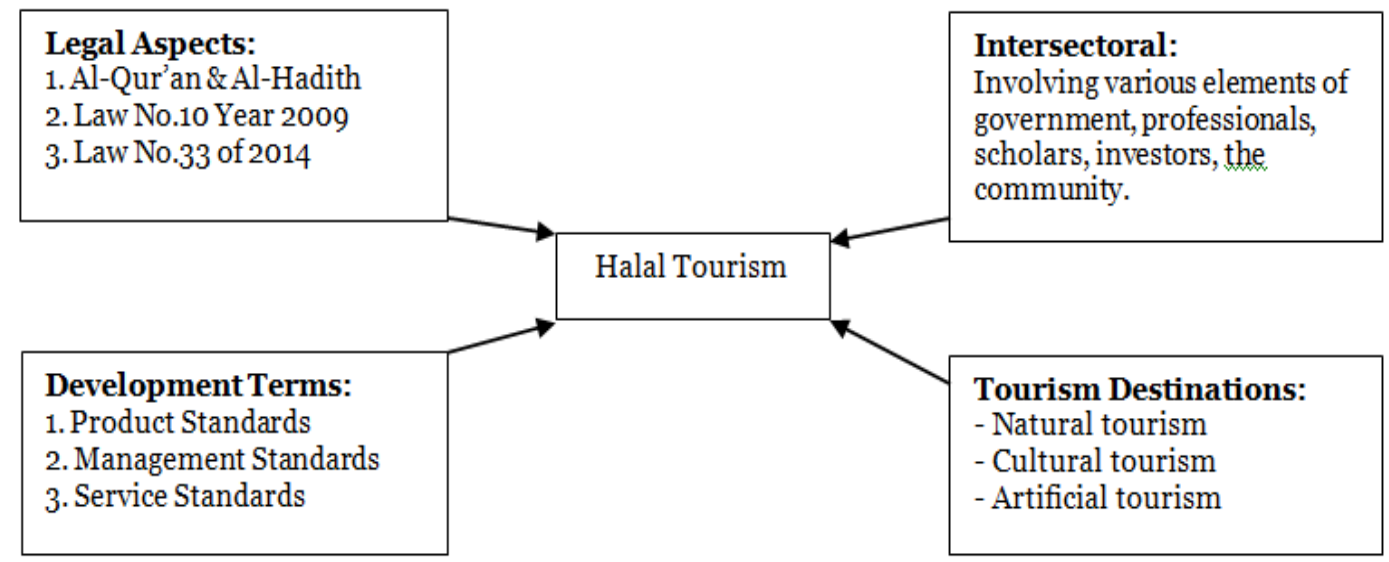

Figure 2. Halal Tourism Development 
In the end, the development of a Halal tourism formation process can be made in the model below in Figure 2. Based on Figure 2, Halal tourism is an object that is still of limited policy, so the communication pattern conveyed to the community is top-down. Which is the practice of top-down communication is more linear. This means that communicators are more powerful than communicants. So that based on a communication analysis the phenomenon of tourism communication models that are formed is more inclined to linear communication patterns.

According to Vardiansyah (2004) one-way linear communication is based on the stimulus-response paradigm, in which local governments in Regencies/cities inevitably have to be able to follow what is a discourse on Halal tourism development at the national and provincial levels. This one-way linear communication model, the emphasis is still on the influence of the mass media on the audience. With the element of involvement, elements of communication can be used as part of a social change strategy.

The important and fun concept of Halal tourism is prioritized as part of excellent service in the tourism sector. The positive impact of tourism development in the form of preservation of the cultures of local communities such as religious activities, customs and traditions, and acceptance of the development of tourism and the arrival of tourists by local communities. Another impact of tourism development is seen from the response of local communities to the existence of tourism such as disputes or conflicts of interest among stakeholders, hatred and rejection of tourism development, and the emergence of social problems such as gambling practices, prostitution and sexual abuse.

The negative impact of tourism, it will arise objection to tourism development. In the view of several community groups, activities tourism is mostly in conflict with Islamic law. The attitude of some people who consider tourism development as contrary to Islamic law basically becomes a challenge especially for tourism policy makers. For anticipate the need for a change in strategy in tourism development. One of them is placing the community not as a tourist attraction that has been happening all this time, but placing the community as the subject of tourism.

\section{CONCLUSION}

The concept of Halal tourism is still limited to the political discourse conveyed by the West Java provincial government. In the perspective of communication studies, the Halal tourism communication model that is formed is still limited to non-binding instructions, but a recommendation if indeed the potential of the planned area has "capital" for development towards Halal tourism destinations in the form of one-step and top-down linear communication. Although the concept of Halal has become a lifestyle for most Muslim populations, Halal tourism is less developed because of facilitation, it is not easy to ensure Halal food, certification Halal, and lack of promotion.

\section{REFERENCES}

Abdullah, S. I. N. W., \& Lui, E. (2018). Satisfaction Drivers and Revisit Intention of International Tourists in Malaysia. Journal of Tourism, Hospitality and Environment Management, 3(9): 1-13.

Akhtar, N., Sun, J., Ahmad, W., \& Akhtar, M.N. (2019). The effect of non-verbal messages on Muslim tourists' interaction adaptation: A case study of Halal restaurants in China. Journal of Destination Marketing \& Management, 11, 10-22.

Vargas-Sánchez, A., \& Moral-Moral, M. (2018). Halal tourism: state of the art, Tourism Review, https://doi.org/10.1108/TR-01-2018-0015. 
Anugrah, K, Mokodongan, Asminar, \& Pulumodoyo, A.Pebriani (2017). Potential Halal Tourism Development in the Support Perspective Availability of Local Halal Restaurants in the City of Gorontalo. Charm Journal, 2(2): 1-12.

Awalia, H. (2017). Commodification of NTB Halal Tourism in Promoting Islamic Tourism Destinations in Indonesia. Journal of Communication Studies, 1(1). 19-30.

Babaoğlan, A.R. (2019). The Future of the Global Muslim Population for 203o. Retrieved from https://www.alibabaoglan.com/blog/the-future-global-muslim-population-2030/ (Acceses on, February, 05, 2019).

Bakar, E. (2013). Model of Tourism and Creative Industry Communication Based on Interactive Maps Online. Journal of Poly Engineering. 8(2): 30-39.

Bashir, A. M., Bayat, A., Olutuase, S. O., \& Abdul Latiff, Z. A. (2019). Factors affecting consumers' intention towards purchasing halal food in South Africa: a structural equation modelling. Journal of Food Products Marketing, 25(1): 26-48.

Battour, M., Hakimian, F., Ismail, M., \& Boğan, E. (2018). The perception of non-Muslim tourists towards halal tourism: Evidence from Turkey and Malaysia. Journal of Islamic Marketing, 9(4): 823-840.

Boğan, E., \& Sarışık, M. (2019). Halal tourism: conceptual and practical challenges. Journal of Islamic Marketing, 10(1): 87-96.

Chianeh, R. H., Soleimanirad, I., Fekri, F., Ahmadi, P., Ghanbari, M., \& Tamaj, Y. R. (2018). Irans Islamic and Halal tourism development challenges. Proceedings Book, 194-203.

Han, H., Al-Ansi, A., Olya, H. G., \& Kim, W. (2019). Exploring halal-friendly destination attributes in South Korea: Perceptions and behaviors of Muslim travelers toward a non-Muslim destination. Tourism Management, 71, 151-164.

Haq, F., \& Medhekar, A. (2019). Is Spiritual Tourism a Peace Vehicle for Social Transformation and Economic Prosperity in India and Pakistan? In Marketing Peace for Social Transformation and Global Prosperity (pp. 189-211). IGI Global.

Hasanah, S., \& Harun, A. N. (2018). Significant Overview of Japan Tourism: Muslim Friendly Destination and Social Media. In 1st Economics and Business International Conference 2017 (EBIC 2017). Atlantis Press.

Heydari, Chianeh, R., Del Chiappa, G., \& Ghasemi, V. (2018). Cultural and religious tourism development in Iran: prospects and challenges. Anatolia, 29(2): 204-214.

Isa, S. M., Chin, P. N., \& Mohammad, N. U. (2018). Muslim tourist perceived value: a study on Malaysia Halal tourism. Journal of Islamic Marketing, 9(2): 402-420.

Kamarudin, L. M., \& Ismail, H. N. (2018). The roles of tour agencies in developing Muslim-friendly tourism packages and its implications to Malaysia. Journal of Fundamental and Applied Sciences, 10(3S): 866-876.

Kaneko, M. (2019). Let's Vacation In Japan! A Study of Indonesian Images of Japan Through Tourism. People: International Journal of Social Sciences, 4(3): 36-48.

Manan, H. A., Ariffin, S., \& Maknu, T. S. R. (2019). Examining Malay Muslims Receptiveness of non-Muslim Country's Halal Food Products. Revista Publicando, 6(19): 275-288.

Mariska, D., \& Shelton, E. J. (2018). Prophet or Profit? Emotional Reflections on Indonesian Tourism. In Asian Qualitative Research in Tourism (pp. 271-288). Springer, Singapore.

Mustafa, E. (2019). Evaluating The Role of Halal Food In Malaysia As An Edu-Tourism Hub: The Case Of Muslim International Students. Journal of Hospitality and Networks, 1(1): 55-63.

Nasution, S.(1996). Research Method. Jakarta: Bumi Akasara.

Nugraha, A.R \& Prastowo, Ari A. (2017). Tourism Communication Through Park City Thematic Branding in Bandung. Prospective Communication, Culture \& Tourism Conference p.183-192.

Nugraha, A.R, Perbawasari, S \& Zubair, F. (2017). Local Wisdom-Based Tourism Communication Model. Journal of The Messenger. 9(2): 21-35.

Nurrachmi, R. (2018). The Global Development of Halal Food Industry: A Survey. Tazkia Islamic Finance and Business Review, 11(1): 67-78.

Oktadiana, H., \& Pearce, P. L. (2018). Motivated Muslims: Exploring Travel Career Patterns Among Indonesian Tourists. In Asian Cultures and Contemporary Tourism (pp. 101-119). Springer, Singapore.

Olya, H. G., \& Al-ansi, A. (2018). Risk assessment of halal products and services: Implication for tourism industry. Tourism Management, 65, 279-291.

Omar, C. M. C. (2019). Exploring The Validation of Islamic Hospitality Management In Tourism Destination: Malaysian Perspectives. Journal of Hospitality and Networks, 1(1): 34-43. 
Omar, C. M. C. (2019). Exploring The Validation of Islamic Hospitality Management In Tourism Destination: Malaysian Perspectives. Journal of Hospitality and Networks, 1(1): 34-43.

Sarkar, S. K., \& George, B. (2019). Patterns of Tourism and Hospitality Education in India and Malaysia: A Critical Reflection. In Tourism Education and Asia (pp. 227-242). Springer, Singapore.

Sofield, T. (2018). Conflicts, Religion and Culture in Tourism. European Journal of Tourism Research, 20, $159-163$.

Subana \& Sudrajat. (2011). Basics of Scientific Research. Bandung: Loyal Library.

Suharko, S., Khoiriati, S. D., Krisnajaya, I., \& Dinarto, D. (2018). Institutional conformance of Halal certification organisation in Halal tourism industry: The cases of Indonesia and Thailand. Turizam: međunarodni znanstveno-stručni časopis, 66(3): 334-348.

Sutono, A. (2019). Supply chain management: implementation issues and research opportunities in tourism industry. Uncertain Supply Chain Management, 7(3): 427-438.

Taylor, S. J., \& Bogdan, R. (1993). Promises made and promises to be broken. The ADA mandate for social change, 255-268.

Thang, H. Q. (2018). Tourism With the Integration and Development of Vietnam-Southeast Asia. International Relations, 6(3): 188-194.

Vardiansyah, D. (2004). Introduction to Communication Studies: Conceptual Taxonomy Approach. Logistics: PT. Ghalia Indonesia.

Vargas Sánchez, A., \& Perano, M. (2018). Halal Tourism through the Lens of Generation Z in a Muslim Majority Country: Implications on Tourist Services. 13(9): 36-49. https://doi.org/10.5539/ijbm.v13n9p36

Waehama, W., Alam, M. M., \& Hayeemad, M. (2018). Challenges and Prospects of Halal Hotel Industry in Muslim and Non-Muslim Countries: Proposed Study on Thailand and Malaysia. Journal of Halal Industry \& Services, 1(1): 23-35.

Wannasupchue, W., Othman, M., Zainal, U. F. U., Abidin, F. A. C. I., \& Mohamad, S. F. (2019). Current Trends and Opportunities for Halal Restaurants in Thailand: A Conceptual Framework. International Journal of Academic Research In Business And Social Sciences, 9(1): 45-58.

Wardi, Y., Abror, A., \& Trinanda, O. (2018). Halal tourism: antecedent of tourist's satisfaction and word of mouth (WOM). Asia Pacific Journal of Tourism Research, 23(5): 463-472.

Yamaguchi, H. K. (2019). The Potential and Challenge Of Halal Foods In Japan. Journal of Asian Rural Studies, 3(1): 1-16.

Yousaf, S., \& Xiucheng, F. (2018). Halal culinary and tourism marketing strategies on government websites: A preliminary analysis. Tourism Management, 68, 423-443.

*** Deputy for Policy Development Tourism. (2015). Final Report Sharia Tourism Development Study. Ministry of Tourism Republic of Indonesia. Jakarta.

*** Laws of The Republic Indonesia. (2009). Number 10 of 2009 about Tourism. Republic of Indonesia. Jakarta.

*** Laws of The Republic Indonesia. (2014). Number 33 of 2014 about Halal Product Certification. Republic of Indonesia. Jakarta.

*** Ministry of Tourism Republic of Indonesia. (2019). Tourism Statistic. Republic of Indonesia. Jakarta. http://www.kemenpar.go.id/asp/ringkasan.asp?c=91.

*** The World Tourism Organization (UNWTO) (2016). UNWTO Tourism Highlights 2016 Edition, http://www.bsa.natcen.ac.uk/downloads/bsa-33-downloads.aspx.

Submitted:

21.01.2019
Revised:

o8.04.2019
Accepted and published online

09.04.2019 